\title{
ARM
}

CLIMATE RESEARCH FACILITY

\section{ARM Surface Meteorology Systems \\ HANDBOOK}

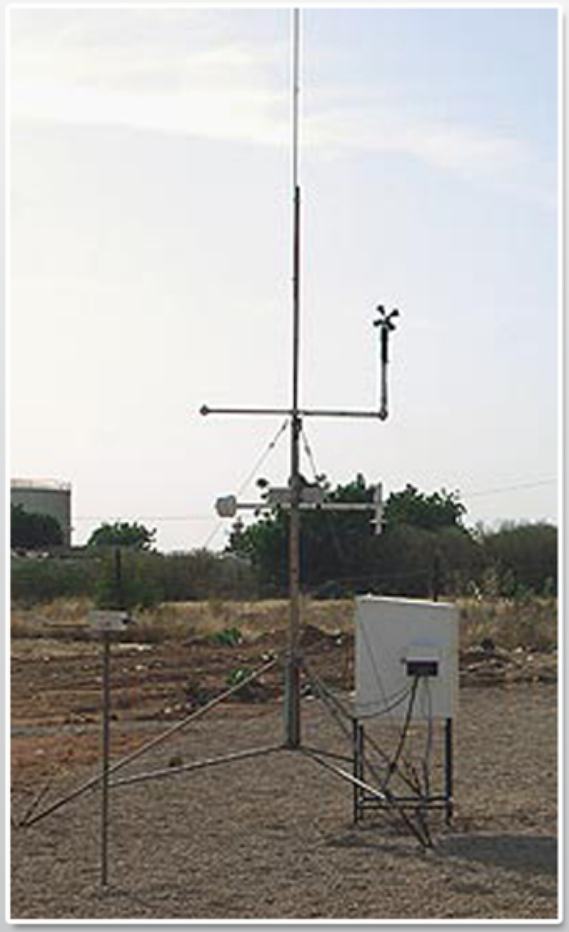

March 2011 


\section{DISCLAIMER}

This report was prepared as an account of work sponsored by the U.S. Government. Neither the United States nor any agency thereof, nor any of their employees, makes any warranty, express or implied, or assumes any legal liability or responsibility for the accuracy, completeness, or usefulness of any information, apparatus, product, or process disclosed, or represents that its use would not infringe privately owned rights. Reference herein to any specific commercial product, process, or service by trade name, trademark, manufacturer, or otherwise, does not necessarily constitute or imply its endorsement, recommendation, or favoring by the U.S. Government or any agency thereof. The views and opinions of authors expressed herein do not necessarily state or reflect those of the U.S. Government or any agency thereof. 


\section{ARM Surface Meteorology Systems (MET) Handbook}

February 2011

Work supported by the U.S. Department of Energy,

Office of Science, Office of Biological and Environmental Research 


\section{Contents}

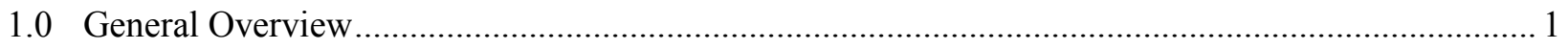

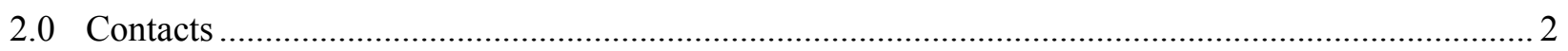

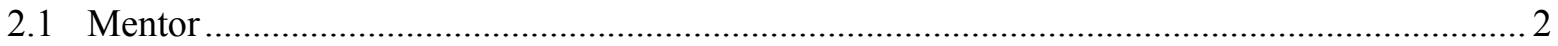

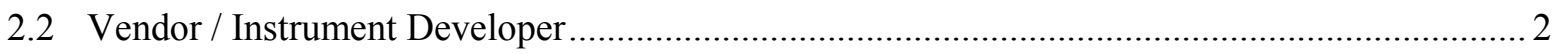

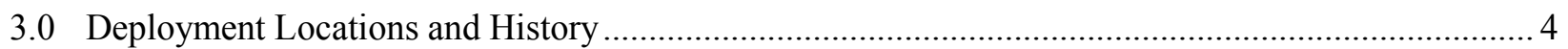

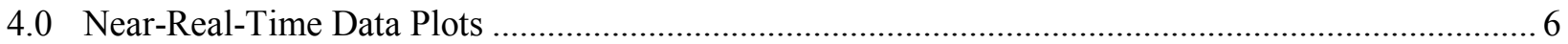

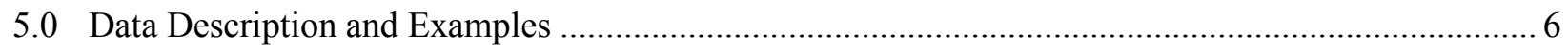

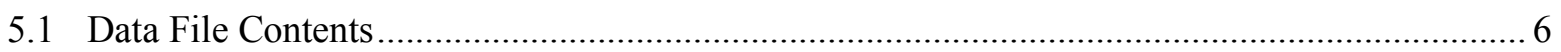

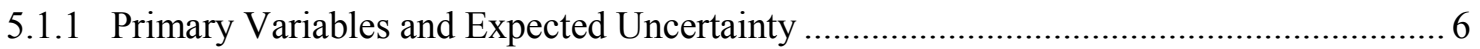

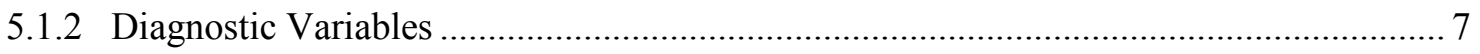

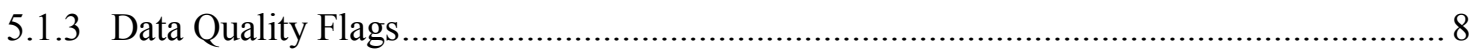

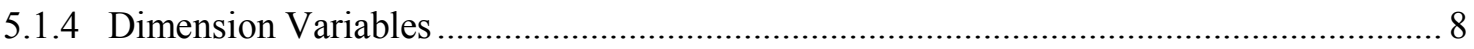

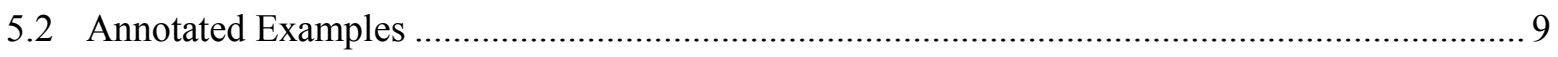

5.3 User Notes and Known Problems .......................................................................... 9

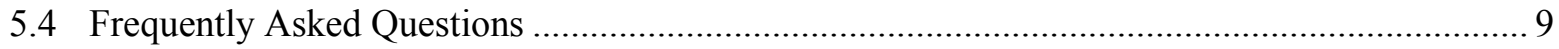

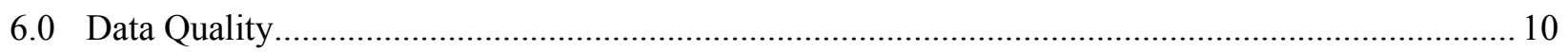

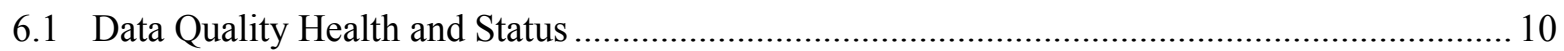

6.2 Data Reviews by Instrument Mentor................................................................................ 10

6.3 Data Assessments by Site Scientist / Data Quality Office ..................................................... 11

6.4 Value-Added Procedures and Quality Measurement Experiments .......................................... 11

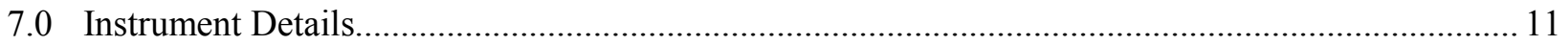

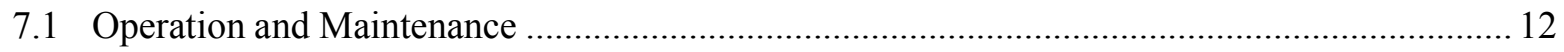

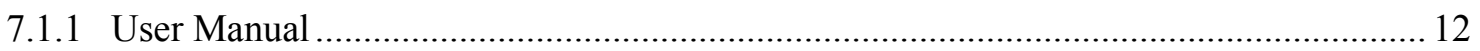

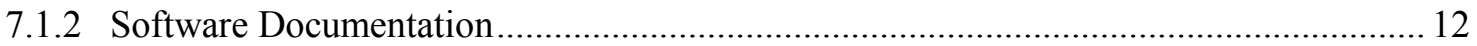

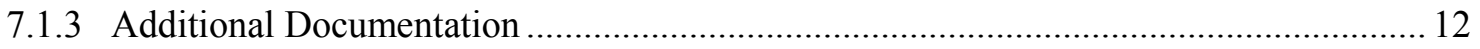

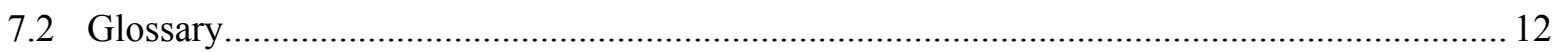

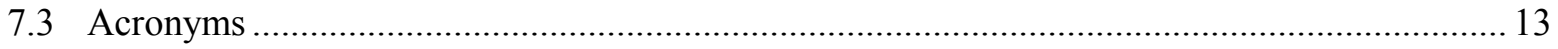

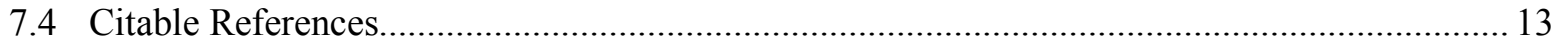




\section{Figures}

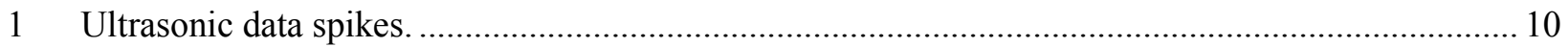

\section{Tables}

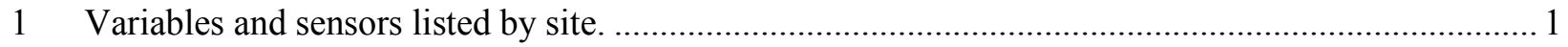

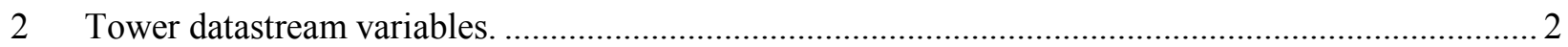

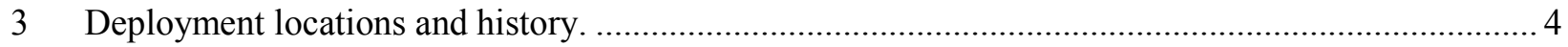

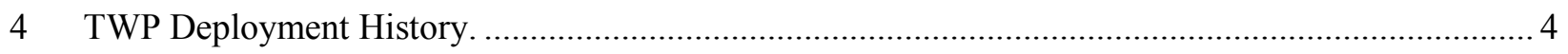

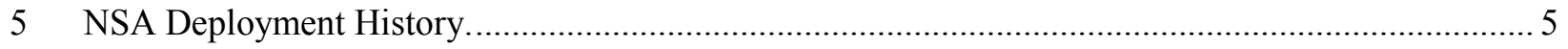

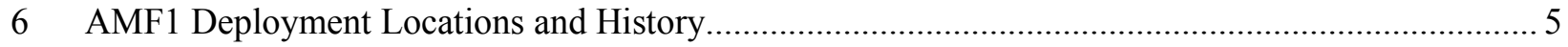

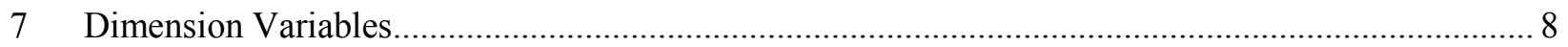




\subsection{General Overview}

The ARM Surface Meteorology Systems consist mainly of conventional in situ sensors that obtain a defined "core" set of measurements. The core set of measurements is: Barometric Pressure (kPa), Temperature $\left({ }^{\circ} \mathrm{C}\right)$, Relative Humidity $(\%)$, Arithmetic-Averaged Wind Speed $(\mathrm{m} / \mathrm{s})$, Vector-Averaged Wind Speed $(\mathrm{m} / \mathrm{s})$, and Vector-Averaged Wind Direction (deg). The sensors that collect the core variables are mounted at the standard heights defined for each variable:

- Winds: 10 meters

- Temperature and Relative Humidity: 2 meters

- Barometric Pressure: 1 meter.

Depending upon the geographical location, different models and types of sensors may be used to measure the core variables due to the conditions experienced at those locations. Most sites have additional sensors that measure other variables that are unique to that site or are well suited for the climate of the location but not at others. The following table lists the variables and the sensors by site.

Table 1. Variables and sensors listed by site.

\begin{tabular}{|c|c|c|c|c|c|c|c|c|c|}
\hline & Barometer & Temp & $\begin{array}{l}\text { Relative } \\
\text { Humidity }\end{array}$ & $\begin{array}{l}\text { Wind } \\
\text { Speed }\end{array}$ & $\begin{array}{c}\text { Wind } \\
\text { Direction }\end{array}$ & $\begin{array}{c}\text { Visibility \& } \\
\text { Present } \\
\text { Weather }\end{array}$ & $\begin{array}{l}\text { Liquid } \\
\text { Precip }\end{array}$ & $\begin{array}{l}\text { Frozen } \\
\text { Precip }\end{array}$ & $\begin{array}{l}\text { Chilled } \\
\text { Mirror }\end{array}$ \\
\hline $\begin{array}{l}\text { SGP } \\
\text { Met }\end{array}$ & $\begin{array}{c}\text { Vaisala } \\
\text { PTB220 }\end{array}$ & $\begin{array}{l}\text { Vaisala } \\
\text { HMP45C }\end{array}$ & $\begin{array}{c}\text { Vaisala } \\
\text { HMP45C }\end{array}$ & $\begin{array}{l}\text { RM } \\
\text { Young } \\
05103\end{array}$ & $\begin{array}{c}\text { RM } \\
\text { Young } \\
05103\end{array}$ & $\begin{array}{c}\text { Vaisala } \\
\text { PWD22 (E13 } \\
\text { only) starting } \\
9 / 9 / 10\end{array}$ & $\begin{array}{c}\text { NovaLynx } \\
\text { TBRG \& } \\
\text { Vaisala } \\
\text { PWD22 (E13 } \\
\text { only) starting } \\
\text { 9/9/10 }\end{array}$ & $\begin{array}{c}\text { Vaisala } \\
\text { PWD22 } \\
\text { (E13 } \\
\text { only) } \\
\text { starting } \\
9 / 9 / 10 \\
\end{array}$ & $\mathrm{~N} / \mathrm{A}$ \\
\hline $\begin{array}{l}\text { NSA } \\
\text { Met }\end{array}$ & $\begin{array}{l}\text { Vaisala } \\
\text { PTB220 }\end{array}$ & $\begin{array}{c}\text { Vaisala } \\
\text { HMT337 }\end{array}$ & $\begin{array}{c}\text { Vaisala } \\
\text { HMT337 }\end{array}$ & $\begin{array}{l}\text { Vaisala } \\
\text { Ultrasonic } \\
\text { WS425 }\end{array}$ & $\begin{array}{l}\text { Vaisala } \\
\text { Ultrasonic } \\
\text { WS425 }\end{array}$ & $\begin{array}{c}\text { Vaisala } \\
\text { FD12P } \\
\text { PWS } \\
\text { replaced by } \\
\text { PWD22 (C1 } \\
\text { only) starting } \\
\text { 10/6/10 }\end{array}$ & $\begin{array}{c}\text { Vaisala } \\
\text { FD12P } \\
\text { PWS replaced } \\
\text { by PWD22 } \\
\text { (C1 only) } \\
\text { starting } \\
\text { 10/6/10 }\end{array}$ & $\begin{array}{c}\text { Vaisala } \\
\text { FD12P } \\
\text { PWS } \\
\text { replaced } \\
\text { by } \\
\text { PWD22 } \\
\text { (C1 only) } \\
\text { starting } \\
10 / 6 / 10\end{array}$ & $\begin{array}{l}\text { TSL } \\
1088 \\
\mathrm{CMH}\end{array}$ \\
\hline $\begin{array}{l}\text { TWP } \\
\text { Met }\end{array}$ & $\begin{array}{c}\text { Vaisala } \\
\text { PTB220 }\end{array}$ & $\begin{array}{l}\text { Vaisala } \\
\text { HMP45D }\end{array}$ & $\begin{array}{l}\text { Vaisala } \\
\text { HMP45D }\end{array}$ & $\begin{array}{l}\text { RM } \\
\text { Young } \\
05106\end{array}$ & $\begin{array}{l}\text { RM } \\
\text { Young } \\
05106\end{array}$ & $\begin{array}{c}\text { Vaisala } \\
\text { PWD22 (C1 } \\
\text { and C3 only) } \\
\text { starting } \\
8 / 26 / 10(\mathrm{C} 1) \\
\text { and } 8 / 17 / 10 \\
\text { (C3) }\end{array}$ & $\begin{array}{c}\text { Optical Sci } \\
\text { ORG } 815 \text { \& } \\
\text { RIMCO } 7499 \\
\text { TBRG \& } \\
\text { Vaisala } \\
\text { PWD22 (C1 \& } \\
\text { C3 only) } \\
\text { starting } \\
\text { 8/26/10 (C1) } \\
\text { and 8/17/10 } \\
\text { (C3) }\end{array}$ & $\begin{array}{c}\text { Vaisala } \\
\text { PWD22 } \\
\text { (C1 and } \\
\text { C3 only) } \\
\text { starting } \\
8 / 26 / 10 \\
\text { (C1) and } \\
\text { 8/17/10 } \\
\text { (C3) }\end{array}$ & $\mathrm{N} / \mathrm{A}$ \\
\hline $\begin{array}{l}\text { AMF } \\
\text { Met }\end{array}$ & $\begin{array}{c}\text { Vaisala } \\
\text { PTB220 }\end{array}$ & $\begin{array}{l}\text { Vaisala } \\
\text { HMP45D }\end{array}$ & $\begin{array}{l}\text { Vaisala } \\
\text { HMP45D }\end{array}$ & $\begin{array}{l}\text { RM } \\
\text { Young } \\
05106\end{array}$ & $\begin{array}{l}\text { RM } \\
\text { Young } \\
05106\end{array}$ & $\begin{array}{l}\text { Vaisala } \\
\text { PWD22 }\end{array}$ & $\begin{array}{c}\text { Vaisala } \\
\text { PWD22 \& } \\
\text { Optical Sci } \\
\text { ORG } 815\end{array}$ & $\begin{array}{l}\text { Vaisala } \\
\text { PWD22 }\end{array}$ & $\mathrm{N} / \mathrm{A}$ \\
\hline $\begin{array}{l}\text { AMF } \\
2 \text { Met }\end{array}$ & $\begin{array}{c}\text { Vaisala } \\
\text { PTB330 }\end{array}$ & $\begin{array}{l}\text { Vaisala } \\
\text { HMP155 }\end{array}$ & $\begin{array}{l}\text { Vaisala } \\
\text { HMP155 }\end{array}$ & $\begin{array}{c}\text { Vaisala } \\
\text { Ultrasonic } \\
\text { WS425 }\end{array}$ & $\begin{array}{l}\text { Vaisala } \\
\text { Ultrasonic } \\
\text { WS425 }\end{array}$ & $\begin{array}{l}\text { Vaisala } \\
\text { PWD22 }\end{array}$ & $\begin{array}{c}\text { Vaisala } \\
\text { PWD22 \& } \\
\text { Optical Sci } \\
\text { ORG 815-DA }\end{array}$ & $\begin{array}{l}\text { Vaisala } \\
\text { PWD22 }\end{array}$ & $\mathrm{N} / \mathrm{A}$ \\
\hline
\end{tabular}


Additionally, the North Slope of Alaska surface meteorology systems are collected from towers. The tower at Barrow has four levels, and the tower at Atqasuk has 2 levels. Two additional datastreams are created using the sensors on the different levels of the towers. The datastreams are arrays with the first value for each variable being the lowest level. The following table describes the variables in the tower datastreams.

Table 2. Tower datastream variables.

\begin{tabular}{|c|c|c|c|c|}
\hline & Temp & RH & WS & WD \\
\hline NSATWRC1 & $2,10,20,40 \mathrm{~m}$ & $2,10,20,40 \mathrm{~m}$ & $2,10,20,40 \mathrm{~m}$ & $2,10,20,40 \mathrm{~m}$ \\
\hline NSATWRC2 & $2 \mathrm{~m}$ and $5 \mathrm{~m}$ & $2 \mathrm{~m}$ and $5 \mathrm{~m}$ & N/A in Met data & N/A in Met data \\
\hline
\end{tabular}

\subsection{Contacts}

\subsection{Mentor}

Michael T. Ritsche

Assistant Meteorologist

Argonne National Laboratory

Bldg. 203, RM J-175

Argonne, IL 60439

Phone: (630) 252-1554

Fax: (630) 252-5498

Email: mtritsche@anl.gov

Jenni Prell

Associate Mentor

Argonne National Laboratory

Bldg. 203, RM J-147

Argonne, IL 60439

Phone: (630) 252-7662

Fax: (630) 252-2959

Email: jprell@anl.gov

\subsection{Vendor / Instrument Developer}

Data loggers (CR10, CR10X, CR1000, CR23X, CR3000)

Campbell Scientific Inc.

815 W. $1800 \mathrm{~N}$.

Logan, UT 84321

Phone: (801) 753-2342

Fax: (801) 750-9540

Website: http://www.campbellsci.com 


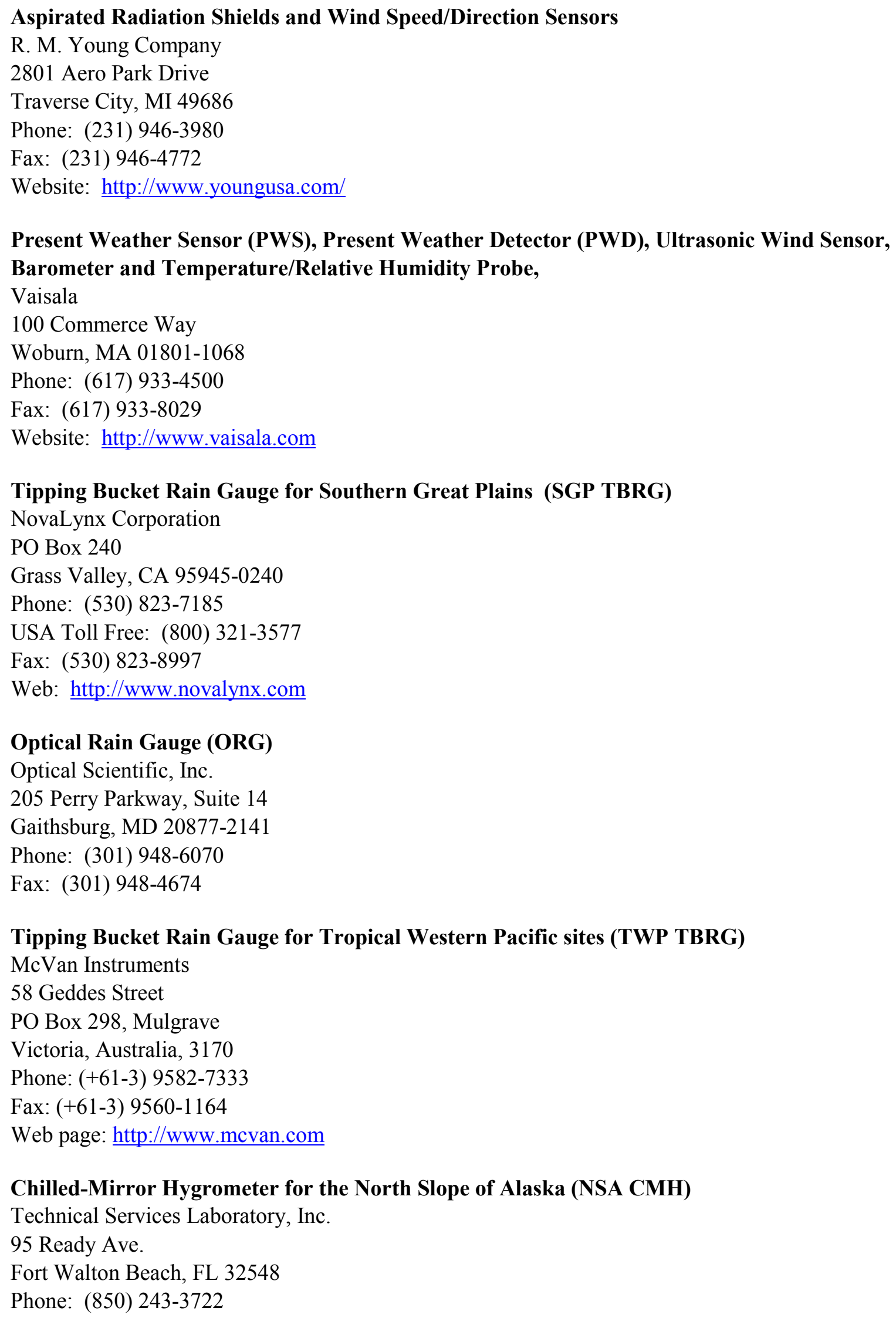




\section{Fiber Driver}

Allied Telesys

19800 North Creek Parkway, Suite 200

Bothell, WA 98011

Phone: (425) 487-8880

Fax: (425) 489-9191

Toll-free: 1-800-424-6596 (U.S. only)

Web page: http://www.alliedtelesis.com/

\subsection{Deployment Locations and History}

Table 3. Deployment locations and history.

\begin{tabular}{|c|c|c|c|}
\hline Location & Date Installed & Date Removed & Status \\
\hline E1-Larned, KS & $1995 / 08 / 29$ & $2010 / 10 / 15$ & Decommissioned \\
\hline E3-LeRoy, KS & $1995 / 12 / 12$ & $2010 / 10 / 28$ & Decommissioned \\
\hline E4-Plevna, KS & $1995 / 03 / 28$ & & Operational \\
\hline E5-Halstead, KS & $1996 / 05 / 30$ & $2010 / 11 / 2$ & Decommissioned \\
\hline E6-Towanda, KS & $1995 / 12 / 14$ & & Operational \\
\hline E7-Elk Falls, KS & $1995 / 03 / 09$ & & Operational \\
\hline E8-Coldwater, KS & $1993 / 03 / 30$ & $2010 / 11 / 10$ & Decommissioned \\
\hline E9-Ashton, KS & $1993 / 03 / 31$ & & Operational \\
\hline E11-Byron, OK & $1995 / 06 / 23$ & & Operational \\
\hline E13 (CF)-Lamont, OK & $1993 / 03 / 29$ & & Operational \\
\hline E15-Ringwood, OK & $1993 / 04 / 01$ & & Operational \\
\hline E20-Meeker,OK & $1993 / 04 / 02$ & & Operational \\
\hline E21-Okmulgee,OK & $1999 / 07 / 27$ & & Operational \\
\hline E24-Cyril, OK & $1995 / 08 / 23$ & $2010 / 11 / 24$ & Decommissioned \\
\hline E25-Seminole, OK & $1996 / 12 / 13$ & $2002 / 04 / 08$ & Decommissioned \\
\hline E27-Earlsboro, OK & $2002 / 05 / 02$ & $2010 / 01 / 20$ & Decommissioned \\
\hline
\end{tabular}

Table 4. TWP Deployment History.

\begin{tabular}{|c|c|c|c|c|}
\hline Location & Date Installed & $\begin{array}{c}\text { Date LoggerNet } \\
\text { Upgrade }\end{array}$ & Date Removed & Status \\
\hline TWP C1 Manus & $10 / 1996$ & $08 / 2004$ & & Operational \\
\hline TWP C2 Nauru & $11 / 1998$ & $07 / 2004$ & & Operational \\
\hline TWP C3 Darwin & $04 / 2002$ & $05 / 2004$ & & Operational \\
\hline
\end{tabular}

Table 2 contains the additional column of "Date LoggerNet Upgrade". On this date major changes were made to the way the data were collected, which included adding new variables and removing others. 
Table 5. NSA Deployment History.

\begin{tabular}{|c|c|c|c|c|c|}
\hline Location & Date Installed & $\begin{array}{c}\text { Date } \\
\text { LoggerNet } \\
\text { Upgrade }\end{array}$ & $\begin{array}{c}\text { Date T/RH and } \\
\text { Ultrasonic } \\
\text { Upgrade }\end{array}$ & $\begin{array}{c}\text { Date } \\
\text { Removed }\end{array}$ & Status \\
\hline $\begin{array}{c}\text { NSA C1 } \\
\text { Barrow, AK }\end{array}$ & $03 / 1998$ & $10 / 2003$ & $09 / 2008$ & & Operational \\
\hline $\begin{array}{c}\text { NSA C2 } \\
\text { Atqasuk, AK }\end{array}$ & $07 / 2000$ & $10 / 2003$ & $09 / 2008$ & $01 / 16 / 2011$ & Decommissioned \\
\hline
\end{tabular}

Table 3 contains two additional columns of "Date LoggerNet Upgrade" and "Date T/RH and Ultrasonic Upgrade". On these date major changes were made to the way the data were collected, which included adding new variables and removing others. In the case of the Date of LoggerNet Upgrade, some sensors were removed altogether. At NSAC1 the Optical Rain Gauge was removed and one that measured every minute replaced the $\mathrm{CMH}$ that measured once every 15 minutes. At NSAC2 the ultrasonic snow depth sensor was removed.

Table 6. AMF1 Deployment Locations and History.

\begin{tabular}{|c|c|c|c|}
\hline Location & Start Date & End Date & Sensors Deployed \\
\hline $\begin{array}{l}\text { Pt. Reyes, Ca } \\
\text { (PYE M1) }\end{array}$ & $02 / 01 / 2005$ & 09/15/2005 & $\begin{array}{l}\text { HMP-45D T/RH probe, } 05106 \text { Wind Monitor, PTB-220 } \\
\text { Barometer, } 815 \text { and } 115 \text { Optical Rain Gauge }\end{array}$ \\
\hline $\begin{array}{l}\text { Niamey, Niger } \\
\quad \text { (NIM M1) }\end{array}$ & $01 / 05 / 2006$ & $01 / 07 / 2007$ & $\begin{array}{l}\text { HMP-45D T/RH probe, } 05106 \text { Wind Monitor, PTB-220 } \\
\text { Barometer, } 815 \text { and } 115 \text { Optical Rain Gauge, PWD- } \\
22 \text { Present Weather Detector }\end{array}$ \\
\hline $\begin{array}{l}\text { Niger Ancillary } \\
\text { Site } \\
\text { (Bazimboubou, } \\
\text { Niger) (NIM S1) }\end{array}$ & $01 / 05 / 2006$ & $12 / 08 / 2006$ & $\begin{array}{l}\text { HMP-45AC T/RH probe, } 05106 \text { Wind Monitor, PTB- } \\
220 \text { Barometer, } 815 \text { and } 115 \text { Optical Rain Gauge, }\end{array}$ \\
\hline $\begin{array}{l}\text { Hasselbach, } \\
\text { Germany } \\
\text { (FKB M1) }\end{array}$ & $04 / 02 / 2007$ & $01 / 01 / 2008$ & $\begin{array}{l}\text { HMP-45D T/RH probe, } 05106 \text { Wind Monitor, PTB-220 } \\
\text { Barometer, } 815 \text { and } 115 \text { Optical Rain Gauge, PWD- } \\
22 \text { Present Weather Detector }\end{array}$ \\
\hline $\begin{array}{l}\text { Shouxian, China } \\
\text { (HFE M1) }\end{array}$ & $05 / 2008$ & $12 / 2008$ & $\begin{array}{l}\text { HMP-45D T/RH probe, } 05106 \text { Wind Monitor, PTB-220 } \\
\text { Barometer, } 815 \text { and } 115 \text { Optical Rain Gauge, PWD- } \\
22 \text { Present Weather Detector }\end{array}$ \\
\hline $\begin{array}{l}\text { China Ancillary } \\
\text { Site } \\
\text { (Taihu, China) } \\
\text { (HFE S1) }\end{array}$ & $05 / 2008$ & $12 / 2008$ & $\begin{array}{l}\text { HMP-45AC T/RH probe, } 05106 \text { Wind Monitor, PTB- } \\
220 \text { Barometer, } 815 \text { and } 115 \text { Optical Rain Gauge, }\end{array}$ \\
\hline $\begin{array}{l}\text { Graciosa, } \\
\text { Azores }\end{array}$ & $05 / 2009$ & $01 / 07 / 2011$ & $\begin{array}{l}\text { HMP-45D T/RH probe, } 05106 \text { Wind Monitor, PTB-220 } \\
\text { Barometer, } 815 \text { and } 115 \text { Optical Rain Gauge, PWD- } \\
22 \text { Present Weather Detector }\end{array}$ \\
\hline
\end{tabular}

Table 4 contains the additional column for "Sensors Deployed". This is a result of the fact that the AMF has an ancillary site that is deployable in case the main site does not have an optimal location. The ancillary site typically does not have all the same sensors and so the variables are different. Additionally, given the climate of the region certain sensors may not be useful. For example, the ORG should not be used for frozen precipitation measurements and will be removed from the instrument list during arctic deployments. 


\subsection{Near-Real-Time Data Plots}

Near-real-time data plots can be found at the following locations:

http://www.arm.gov/data/plots

\subsection{Data Description and Examples}

\subsection{Data File Contents}

\subsubsection{Primary Variables and Expected Uncertainty}

The following links lead to tables that list the information for the primary variables, their long names, units, measurement level and interval and resolution. Primary Variables are different than the "Core" variables in that they are all the variables measured at the given location from all the meteorological system sensors. For example, the SGP MET "Core" variables are Barometric Pressure (kPa), Temperature $\left({ }^{\circ} \mathrm{C}\right)$, Relative Humidity $(\%)$, Arithmetic Averaged Wind Speed $(\mathrm{m} / \mathrm{s})$, Vector-Averaged Wind Speed $(\mathrm{m} / \mathrm{s})$, and Vector-Averaged Wind Direction (deg). The SGP Primary Variables also contain the precipitation measured form the tipping bucket rain gauge and a corrected precipitation measurement and the calculated vapor pressure.

- $\underline{\text { SGP MET Primary Variables }}$

- $\underline{\text { NSA MET Primary Variables }}$

- NSA TWR C1 Primary Variables

- NSA TWR C2 Primary Variables

- $\underline{\text { TWP MET Primary Variables }}$

AMF MET Primary Variables

- Point Reyes, California

- Niamey, Niger

- Niger Ancillary Site (Bizamboubou, Niger)

- Heselbach, Germany

- $\underline{\text { Shouxian, China }}$

- China Ancillary Site (Taihu, China)

- Graciosa, Azores

- Steamboat Springs, Colorado (currently unavailable) 


\subsubsection{Definition of Uncertainty}

We define uncertainty as the range of probable maximum deviation of a measured value from the true value within a $95 \%$ confidence interval. Given a bias (mean) error $B$ and uncorrelated random errors characterized by a variance $\sigma^{2}$, the root-mean-square error (RMSE) is defined as the vector sum of these,

$$
R M S E=\left(B^{2}+\sigma^{2}\right)^{1 / 2}
$$

( $B$ may be generalized to be the sum of the various contributors to the bias and $\sigma^{2}$ the sum of the variances of the contributors to the random errors). To determine the $95 \%$ confidence interval we use the Student's $t$ distribution: $t_{\mathrm{n} ; 0.025} \approx 2$, assuming the RMSE was computed for a reasonably large ensemble. Then the uncertainty is calculated as twice the RMSE.

\subsubsection{Secondary/Underlying Variables}

This section is not applicable to the ARM surface meteorology systems.

\subsubsection{Diagnostic Variables}

Diagnostic variables are typically variables that do not have a scientific value but instead allow for determination of the proper function of the sensors and system components. For example, Battery Voltage, Error Codes, and standard deviations of the Primary Variables are contained in these tables.

- $\underline{\text { SGP MET Diagnostic Variables }}$

- NSA MET Diagnostic Variables

- $\underline{\text { NSA TWR C1 Diagnostic Variables }}$

- $\underline{\text { NSA TWR C2 Diagnostic Variables }}$

- $\underline{\text { TWP MET Diagnostic Variables }}$

AMF MET Diagnostic Variables

- $\underline{\text { Point Reyes, California }}$

- Niamey, Niger

- Niger Ancillary Site (Bizamboubou, Niger)

- Heselbach, Germany

- $\underline{\text { Shouxian, China }}$

- China Ancillary Site (Taihu, China)

- $\underline{\text { Graciosa, Azores }}$

- Steamboat Springs, Colorado (currently unavailable) 


\subsubsection{Data Quality Flags}

Data Quality Flags are additional variables inserted into the datastream during routine collection and ingest. These variables are a flag to assist in the checking the quality of the data collected. The following tables list the maximum, minimum, and delta values for each variable that will cause the QC variable to be set.

- $\underline{\text { SGP MET Data Quality Flags }}$

- NSA MET Data Quality Flags

- NSA TWR C1 Data Quality Flags

- NSA TWR C2 Data Quality Flags

- $\underline{T W P}$ MET Data Quality Flags

AMF MET Data Quality Flags

- $\underline{\text { Point Reyes, California }}$

- Niamey, Niger

- Niger Ancillary Site (Bizamboubou, Niger)

- Heselbach, Germany

- Shouxian, China

- China Ancillary Site (Taihu, China)

- Graciosa, Azores

- Steamboat Springs, Colorado (currently unavailable)

\subsubsection{Dimension Variables}

The dimension variables are the same for all datastreams regardless of site.

Table 7. Dimension Variables

\begin{tabular}{|c|c|c|}
\hline Variable & $\begin{array}{l}\text { Measurement } \\
\text { Interval }\end{array}$ & Unit \\
\hline base_time & $1 \mathrm{~min}$ & seconds since $\mathrm{YYYY}$-mm-dd $\mathrm{XX}: \mathrm{XX}: \mathrm{XX} \mathrm{X}: \mathrm{XX}$ \\
\hline time_offset & $1 \mathrm{~min}$ & seconds since $Y Y Y Y-m m-d d X X: X X: X X X: X X$ \\
\hline time & $1 \mathrm{~min}$ & seconds since $Y Y Y Y-m m-d d X X: X X: X X X: X X$ \\
\hline lat & $1 \mathrm{~min}$ & degrees \\
\hline Ion & $1 \mathrm{~min}$ & degrees \\
\hline alt & $1 \mathrm{~min}$ & meters above sea level \\
\hline
\end{tabular}

NOTE: lat/lon/alt refers to the ground where the instrument is sited, NOT the height of the sensor. The Dimension Variables are not separated out by site since these are common to all locations. 


\subsection{Annotated Examples}

None.

\subsection{User Notes and Known Problems}

This section contains detailed information about known problems and issues with the sensors or system that may be of importance to the end data user. Examples of data during problems and data plots are sometimes included in order to better explain the problem. In most cases, the known problems are cases of poor data that occur due to routine maintenance, self-cleaning by sensors, etc. that affect the data quality.

- SGP MET User Notes and Known Problems

- NSA MET User Notes and Known Problems

- 2003-2008

- 2008-present

- NSA TWRC1 User Notes and Known Problems

$-\underline{2003-2008}$

- 2008-present

- NSA TWRC2 User Notes and Known Problems

- $\underline{2003-2008}$

- 2008-present

- TWP MET User Notes and Known Problems

- AMF1 MET User Notes and Known Problems

- $\underline{\text { AMF2 MET User Notes and Known Problems }}$

\subsection{Frequently Asked Questions}

\section{Where can SGPMET-like data be obtained for extended facilities that do not have SGPMET} systems?

Several sources of surface meteorological data exist and are available as "external data" to ASR science team members. The Oklahoma Mesonet has more than 50 surface stations within the boundaries of the SGP site, the Kansas State network has 4-5 stations, and each of the boundary facilities has a surface meteorological station associated with the 404-MHz radar wind profiler operated by the National Oceanic and Atmospheric Administration. The status and contacts for external data can be found on the Web at location http://www.arm.gov/instruments/okm. 


\section{Where can I find Ultrasonic Wind Data at the NSA C1 site prior to $2008 ?$}

A Vaisala WS425 Ultrasonic wind sensor was mounted at the $2 \mathrm{~m}$ level on the Barrow Met tower from 2003 through 2008 as a preliminary test to determine its robustness and capabilities in an arctic environment. The data from this sensor can be found here: https://engineering.arm.gov/tool/dod/showdod.php? Inst=mettwr4h\&View=devA.

The WS425 uses ultrasound to determine the horizontal wind speed and direction. It measures the transit time it takes for the pulse to travel from one transducer head to another. For wind speed, Vaisala quotes a starting threshold and delay distance of virtually zero, measurement range of 1 to $65 \mathrm{~m} / \mathrm{s}$, resolution of $0.1 \mathrm{~m} / \mathrm{s}$, and an accuracy of $+/-0.135$ or $3 \%$ of reading (whichever is greater) over the measuring range. For wind direction, Vaisala quotes the same starting threshold and delay distance as above, a resolution of $1^{\circ}$, and an accuracy of $+/-2^{\circ}$. The maximum reading rate for this sensor is once per second.

At times the data from the Ultrasonic wind speed and direction sensor is poor due to heavy, wet snow. When this occurs the Ultrasonic sensor outputs -6999 or -9999 . The datalogger attempts to convert the poor or missing data values to vector averages. As the missing or poor data may only be a few seconds in a minute the values are averaged into the minute values and show up as spikes in the data. See Figure 1 below.

Sonic Wind Speed and Direction

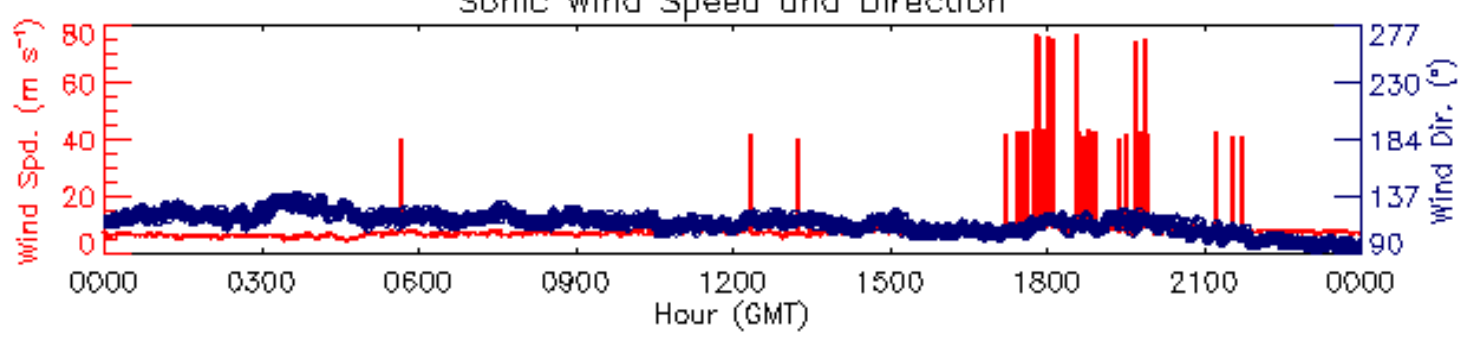

Figure 1. Ultrasonic data spikes.

\subsection{Data Quality}

\subsection{Data Quality Health and Status}

Data Quality Health and Status (DQ HandS), http://dq.arm.gov.

NCVweb - for interactive data plotting using, http://dq.arm.gov/ncvweb/ncvweb.cgi.

\subsection{Data Reviews by Instrument Mentor}

The Data Quality Office sends out weekly reports on each system on a weekly basis. These reports are viewed by the mentor. Any issues requiring mentor intervention or actions are handled at this time. Mentor Reports that include the Data Quality Office reports and spot checking of all systems are created monthly. 


\subsection{Data Assessments by Site Scientist / Data Quality Office}

The ARM Data Quality Office uses the Data Quality Assessment (DQA) system to inform the ARM Site Operators, Site Scientists, and Instrument Team members of instrument and data flow problems as well as general data quality observations. The routine assessment reports are performed on the most recently collected ARM data and used with the Data Quality Problem reports tool to initiate and track the problem resolution process: http://www.db.arm.gov/DQA/

\subsection{Value-Added Procedures and Quality Measurement Experiments}

Many of the scientific needs of the Atmospheric Radiation Measurement (ARM) Climate Research Facility are met through the analysis and processing of existing data products into "value-added" products (VAPs). Despite extensive instrumentation deployed at the ARM sites, there will always be quantities of interest that are either impractical or impossible to measure directly or routinely. Physical models using ARM instrument data as inputs are implemented as VAPs and can help fill some of the unmet measurement needs of the program. Conversely, ARM produces some VAPs not to fill unmet measurement needs, but to improve the quality of existing measurements. In addition, when more than one measurement is available, ARM also produces "best-estimate" VAPs. A special class of VAP, called a Quality Measurement Experiment (QME), does not output geophysical parameters of scientific interest. Instead, a QME adds value to the input datastreams by providing for continuous assessment of the quality of the input data based on internal consistency checks, comparisons between independent similar measurements, or comparisons between measurement with modeled results, and so forth. For more information, see the VAPs and QMEs web page at http://www.arm.gov/data/vaps.

\subsection{Instrument Details}

The following detailed information about the instrument can be viewed by clicking on the appropriate link for each individual system.

- $\underline{\text { SGP MET Instrument Details }}$

- NSA MET Instrument Details

$-\underline{2003-2008}$

- 2008-present

- NSA TWRC1 Instrument Details

$-\underline{2003-2008}$

- 2008-present

- NSA TWRC2 Instrument Details

- 2003-2008

- 2008-present

- $\underline{\text { TWP MET Instrument Details }}$ 
- AMF1 MET Instrument Details

- $\underline{\text { AMF2 MET Instrument Details }}$

\subsection{Operation and Maintenance}

\subsubsection{User Manual}

Users can click on the following links in order to view the very detailed User Manual for each system. These user manuals contain information such as wiring diagrams, calibration procedures, daily and weekly checks. Examples of the program that resides on the data logger and setup procedures are also located here.

- SGP MET User Manual

- NSA C1 MET \& TWR User Manual

- NSA C2 MET \& TWR User Manual

- TWP MET User Manual

- $\underline{\text { AMF1 MET User Manual }}$

- AMF2 MET User Manual (not available)

\subsubsection{Software Documentation}

ARM netCDF file header descriptions may be found for each of the systems can be found by following the link below

- https://engineering.arm.gov/tool/dod/showdod.php?Inst=met\&View=dev

\subsubsection{Additional Documentation}

This section is not applicable to this instrument.

\subsection{Glossary}

Barometric pressure: Local station pressure measured at station at a height of $1 \mathrm{~m}$.

Relative humidity: Percentage of saturated vapor pressure at the specified temperature.

Vector-averaged wind speed: Wind speed computed as the vector sum of the orthogonal $\mathrm{u}$ and $\mathrm{v}$ components that are computed for each sample of wind speed and direction. The wind directions reported are determined from the vector-averaged winds.

Wind Monitor: Trade name for R.M. Young propeller anemometer and wind vane.

See the ARM Glossary at http://www.arm.gov/about/glossary. 


\subsection{Acronyms}

$\begin{array}{ll}\text { AC } & \text { alternating current } \\ \text { A/D } & \text { Analog to Digital converter } \\ \text { CMH } & \text { chilled mirror hygrometer } \\ \text { DQA } & \text { Data Quality Assessment } \\ \text { DQO } & \text { Data Quality Office } \\ \text { NIST } & \text { National Institute of Standards and Technology } \\ \text { QME } & \text { Quality Measurement Experiment } \\ \text { RH } & \text { Relative Humidity } \\ \text { rms } & \text { root mean square } \\ \text { SGP } & \text { Southern Great Plains } \\ \text { T/RH } & \text { temperature/relative humidity (sensor) } \\ \text { VAP } & \text { value-added product } \\ \text { TBRG } & \text { tipping bucket rain gage } \\ \text { ORG } & \text { optical rain gauge } \\ \text { PWD } & \text { Present Weather Detector } \\ \text { PWS } & \text { Present Weather Sensor }\end{array}$

Also see the ARM Acronyms and Abbreviations at http://www.arm.gov/about/acronyms.

\subsection{Citable References}

None. 


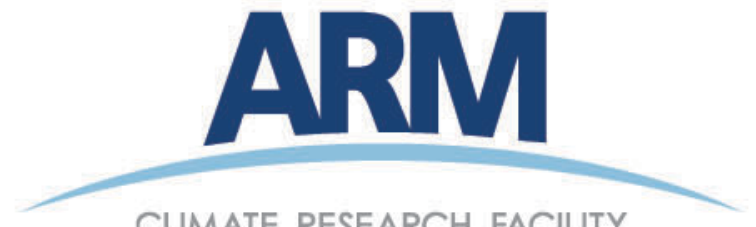

CLIMATE RESEARCH FACILITY

www.arm.gov

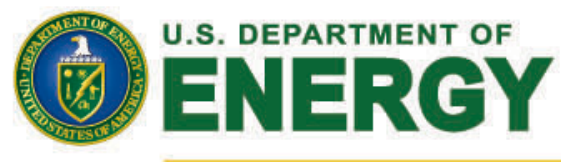

Office of Science 